\title{
The Impact of Entrepreneurial Culture Dimensions on Entrepreneurial Intention: A Cross Cultural Study
}

\author{
Mariem Khadhraoui ${ }^{1}$, Michel Plaisent ${ }^{2, *}$, Lassaad Lakhal ${ }^{3}$, Prosper Bernard $^{2}$ \\ ${ }^{1}$ Management Institute of Sousse, University of Sousse, Tunisia \\ ${ }^{2}$ School of Management Sciences, University of Quebec in Montreal (UQAM), Canada \\ ${ }^{3}$ Faculty of Management and Economic Sciences of Sousse, University of Sousse, Tunisia
}

Copyright $\odot 2016$ by authors, all rights reserved. Authors agree that this article remains permanently open access under the terms of the Creative Commons Attribution License 4.0 International License

\begin{abstract}
This research aims to study the impact of entrepreneurial culture dimensions on the entrepreneurial intention. Six facets of entrepreneurial culture are defined from the literature. The relationship between our dependent and independents variables is measured by the questionnaire of Barbosa and al. [1]. We addressed our questionnaire to 112 students of engineering schools from Canadian and Moroccan engineering schools and we analyzed our research variables using 20.00 version of SPSS. In accordance with previous literature, the results of our survey indicate that there is no direct impact of entrepreneurial culture on the entrepreneurial intention. However, our findings confirm some positive correlations between entrepreneurial culture dimensions and entrepreneurial intention of Canadian and Moroccan engineering school students.
\end{abstract}

Keywords Entrepreneurial Culture, Entrepreneurial Intention, Cross Cultural Study

\section{Introduction}

According to Remeikiene and Startiene [2], "entrepreneurship is one of the main life-force of modern economics growth". It is generally defined as "the creation of new organizations" [3] and viewed as "a context-dependent social process through which individuals and teams create wealth by bringing together unique packages of resources to exploit marketplace opportunities" [4].

In order to establish an entrepreneurship culture, universities are offering entrepreneurial education programs [5] which have a positive impact on students' entrepreneurial attitudes and intention [6,7]. The concept of intention is widely discussed in psychology as well as in management sciences. According to Do Paço and al. [8], intention is defined as a "conscious state of mind that directs attention (and therefore experience and action) toward a specific object (goal) or pathway to achieve it". In the framework of entrepreneurship, entrepreneurial intention is defined as "the commitment to starting a new business" [9] and the propensity to act as the "main forces that make the creation of a firm possible" [10]. Zhao and al. [11] add another definition of entrepreneurial intention. They describe it as "the expressed behavioral intention to become an entrepreneur". Similarly, Zamberi and al. [12] define entrepreneurial intention as "a cognitive representation of the actions to be implemented by individuals to either establish new independent ventures".

Entrepreneurial intention may reflect one's attitude towards entrepreneurship. For example, Crant [13] defines entrepreneurial intention as one's judgments about the likelihood of owning one's own business. Therefore entrepreneurial intention is generally considered as a determinant of future entrepreneurship. For instance, Do Paço and al. [8] consider entrepreneurial intention as "a primary predictor of future entrepreneurial behavior". Also, Maâlaoui and al. [14] define entrepreneurial intention as "the intention of an individual to initiate the entrepreneurial process at some point in the future". Hence, we may define entrepreneurial intention as the commitment to create new business in the future.

In this research, we are interested in the determinants of entrepreneurial intention. More precisely, our object is to assess the impact of entrepreneurial culture on entrepreneurial intention in two different countries; Morocco and Canada. Therefore, we carried out a cross cultural study to answer our research question; what are the entrepreneurial culture dimensions that determine entrepreneurial intention?

\section{Materials}

To explain the determinants of entrepreneurial intention the authors suggest different theories in the previous literature. For instance, Do Paco and al. [8] consider that entrepreneurial intention depends on three general factors: "(1) person's attitude towards the behavior, (2) perceived social norms, and (3) person's self-efficacy". 


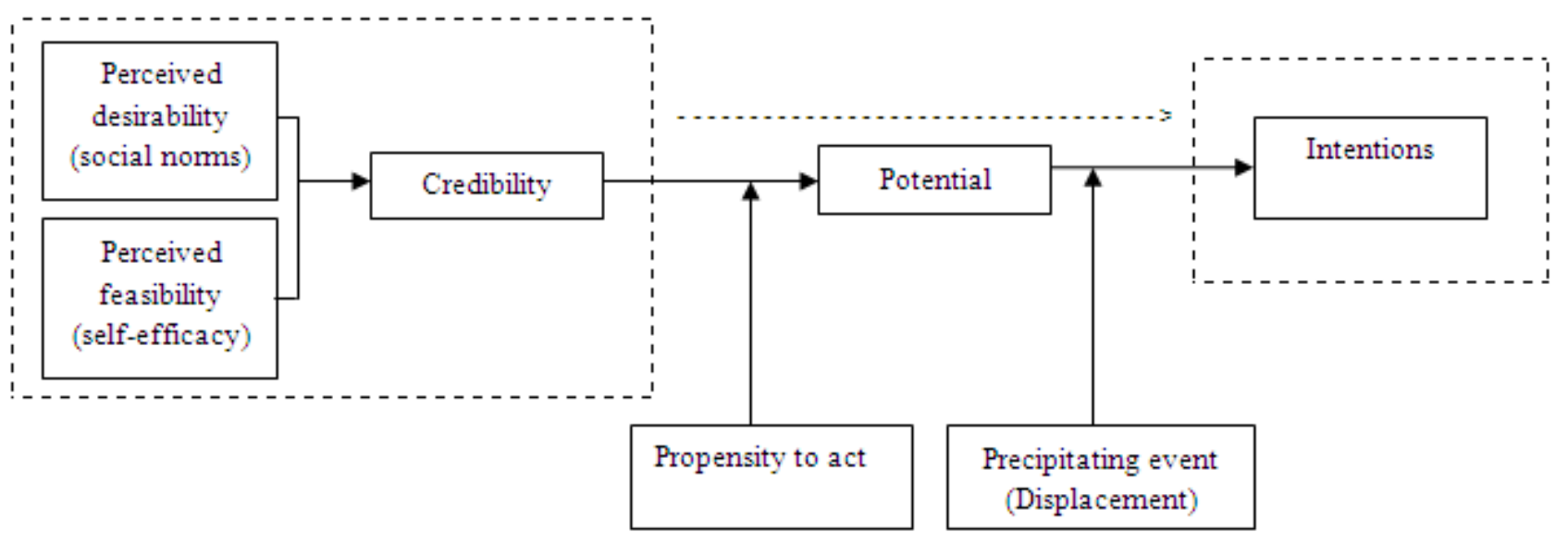

- - Critical constructs considered in this investigation

Figure 1. Entrepreneurial potential model [10] Elaboration based on Krueger and Brazeal [19]

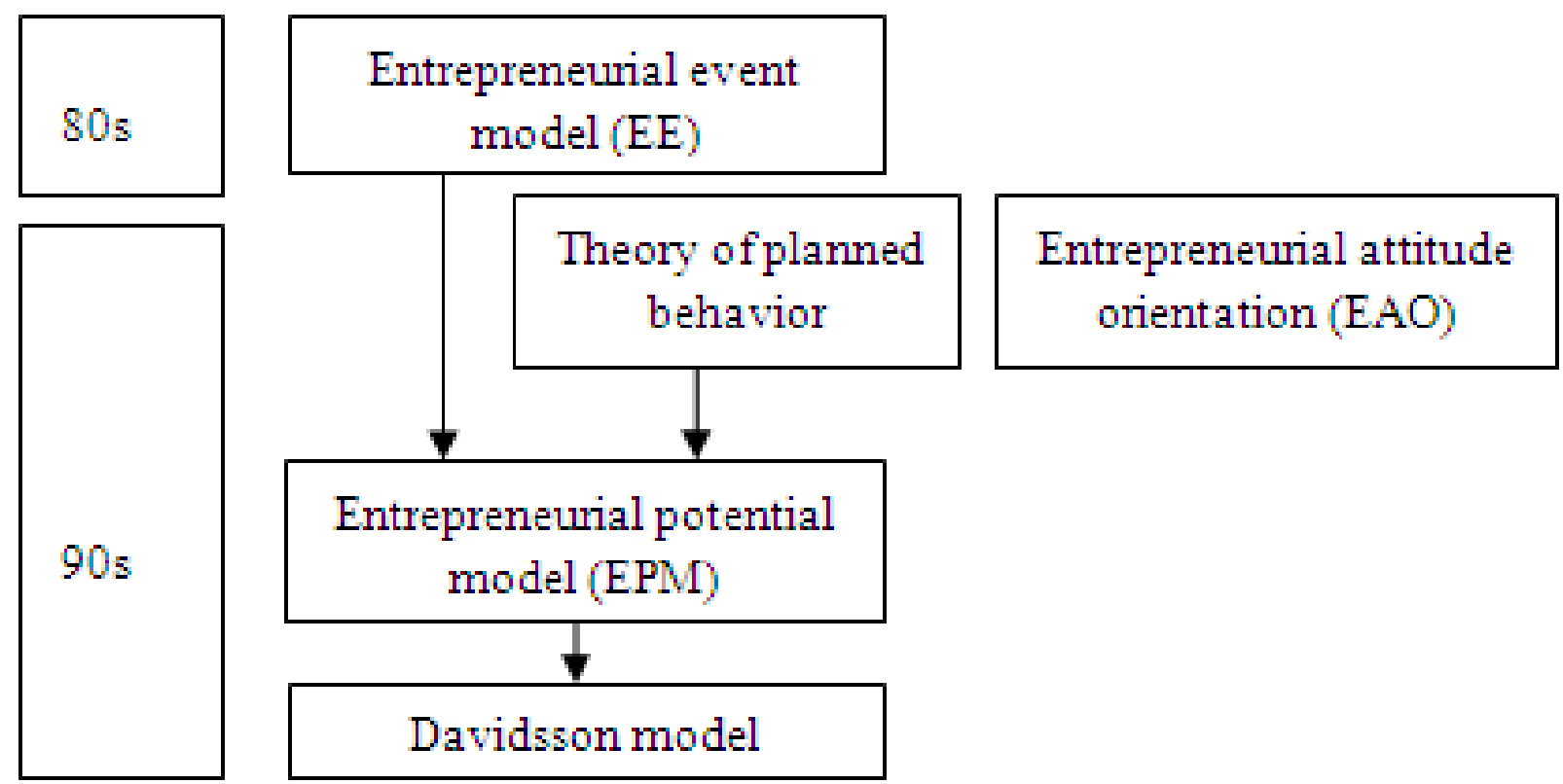

Source; Guerrero [10]

Figure 2. Evolution of entrepreneurial intention model

Moreover, Guerrero et al. [10] emphasize the six main models about entrepreneurial intention (see figure 2). They are:

- Entrepreneurial event model of Shapero [15], with the premise that creating new business as an event that can be denoted by initiative-taking, consolidation of resources, management, relative autonomy, and risk-taking. According to Shapero [15], this paradigm "attempts to include all versions of the entrepreneurial event and all variables (situational, social, and individual) identified with the event".

- Theory of planned behaviour [16]; This theory postulates that perceived behavioral control, attitude, and intention predict behavior.
- Entrepreneurial attitude orientation [17]; This model describes attitude prediction through four sub-scales (achievement, self-esteem, personal control, and innovation) and three different types of reactions (affective, cognitive or conative);

- Intentional basic model [18] that explains the relationship between attitudes and entrepreneurial intentions through a flexible scale that analyzes exogenous influences, attitudes and intentions;

- Entrepreneurial potential model [19] which is integrated by the Entrepreneurial Event Model and the Theory of Planned Behavior. Entrepreneurial potential model supports evidence from two different perspectives, corporate venturing and enterprise development. (see figure 1) 
- Davidsson model [20]; This model postulates that general attitudes, domain attitudes and current situation define the conviction which influences the intention.

Barbosa and al. [1] discussed another determinant of entrepreneurial intention. They adopt the model of Stephan [21] that describes the relationship between entrepreneurial culture and entrepreneurial intention. They carried out an empirical study measuring the impact of different cultural dimensions over entrepreneurial intentions. Therefore, they used a specifically created questionnaire to assess the entrepreneurial culture of a country or a region.

We follow Barbosa and al. [1] and believe that entrepreneurial culture has different influences on entrepreneurial intention depending on the nation.

One of the cultural factors mentioned by Barbosa and al. [1] is managerial skills. They consider that entrepreneurial intention is predicted by ability to manage unexpected situations and to solve difficult and complex problems. They also believe that serenity, self-confidence and improvisation are critical determinants of entrepreneurial orientation. Do Paço and al. [8] also assess the predictors of entrepreneurial intention and they emphasize that managerial skills such as self-confidence and leadership capacity predict the entrepreneurial intention and the propensity for start-ups' creation.

Thus, we postulate that;

\section{H.1. Managerial skills determine the entrepreneurial intention.}

Moreover, Barbosa and al. [1] consider taking responsibility as the second predictor of entrepreneurial orientation. Similarly, Marti and al. [22] note that developing a culture of obligation and responsibility positively influences the collective entrepreneurial culture. Kolb \& Wagner [23] also consider taking responsibility as a critical entrepreneurial trait. Thus, we postulate that;

\section{H.2. Taking responsibility determines the entrepreneurial intention.}

Indeed, the fear of taking responsibility is generally considered as an impediment to entrepreneurial intention since it limits the propensity of self-employment [22] Barbosa and al. [1] note that the fear of taking responsibility in addition to the fear of change, the avoidance of uncertain situations, the hesitation to take risks and the doubt of one's abilities determine the fear of managing business which limits the entrepreneurial intention.

Likewise, the tendency toward risk taking defined as "the preference for situations that can lead to benefits and rewards for succeeding" negatively influences the entrepreneurial intention [24]. Espíritu-Olmos and al. [24] emphasize that risk aversion prevent individuals to consider entrepreneurship because entrepreneurs, often, have to make decisions by assessing risky, ambiguous and uncertain situations. Therefore, the tolerance for ambiguity represents a critical determinant of entrepreneurial intention [25]. Espíritu-Olmos and al. [24] add that tolerance for ambiguity predicts entrepreneurial intention because entrepreneurs deal with uncertain environments.

In the same framework Ekore and Okekeocha [26] consider the fear of change as another impediment of entrepreneurial intention and they note that "the fear of change in entrepreneurship comes about when an individual is worried about change from regular way of life to something new". Thus, we hypothesize that;

\section{H.3. Fear of managing a business limits the entrepreneurial intention.}

In addition, Barbosa and al. [1] argue that individual's entrepreneurial skills such as autonomy, independence, personal initiative and willingness to take risks influence its entrepreneurial intention. Moreover, several authors discuss the impact of entrepreneurial traits on the entrepreneurial intention. For instance, Douglas [27] considers the independence intention as determining factor of entrepreneurial intention. He defines independence intention as "the individual's intention to start a new venture that is primarily expected to allow the individual to 'be one's own boss' while providing an income sufficient to meet his/her needs and/or aspirations". Douglas [27] also highlights that individual's innate need for autonomy positively affects entrepreneurial intention. Moreover, Miller [28] emphasizes that freedom and autonomy are generally associated with self-employment. Therefore, autonomy-oriented individuals are more likely to consider the creation of new business [28]. Personal initiative is also considered as a critical predictor of considering entrepreneurship [29]. Indeed, personal initiative consists of three facets that are indispensible for any future entrepreneur, namely, self-starting action, proactive and future oriented behavior, and overcoming barriers on the way toward the goal [29].

In addition, risk propensity is described in the literature as an entrepreneurial trait that determines the entrepreneurial intention [30]. Zhao et al. [11] argue that people having high score on risk propensity are more attracted to entrepreneurship. Thus, we hypothesize that

\section{H.4. Entrepreneurial traits influence entrepreneurial intention.}

Barbosa and al. [1] also assess the relationship between the tendency to look for opportunities and the entrepreneurial intention. They describe looking for opportunities as looking for new challenges, exploiting small markets, finding several solutions to a problem and perceiving ambiguous situations as opportunities. Barbosa and al. [1] consider these traits as determinants of entrepreneurial intention. Likewise, Douglas [27] explains that "opportunity is provided by the individual's perception of an un-served or under-served market need or an under-utilized resource". He considers that seizing this opportunity is necessary to consider any entrepreneurial action. Moreover, Cardon and al. [31] 
consider the looking for opportunities as a critical entrepreneurial character that allows the recognition and exploitation of business opportunities which is the core of future entrepreneur missions. Thus, we hypothesize that

\section{H.5. Looking for opportunities determines entrepreneurial intention.}

Barbosa and al. [1] consider entrepreneurial motivation as another crucial factor that predicts entrepreneurial intention. Entrepreneurial motivation may be explained by considering entrepreneurship as a desirable career choice, a guarantee of freedom and independence and a way to realize one's ideas and to achieve success as well as a chance to improve one's financial situation [1]. Similarly, Douglas [27] notes that entrepreneurial motive "is provided when the particular new venture is perceived to be the most desirable career option". They add that "individuals will be motivated to start a new business venture if it promises them the greatest expected psychic satisfaction or "utility". According to Locke and Latham [32], "The concept of motivation refers to internal factors that impel action and to external factors that can act as inducements to action". Eijdenberg and Masurel [33] adopt this definition and use it to divide entrepreneurial motivations into push factors and pull factors. They describe "pulled" entrepreneurs as individuals that are spontaneously attracted to self-employment and "pushed" entrepreneurs as individuals that are dissatisfied with their current situations and pushed to create a business.

Shane and al. [34] also studied the impact of entrepreneurial motivation on entrepreneurial intention. They were based on a broad meta-analysis to develop a model for entrepreneurial motivation. Their results indicate that the most significant factors of entrepreneurial motivation are the need for achievement; a person's locus of control; desire for independence; vision; passion; drive; a person's goal-setting; and self-efficacy. Thus, we hypothesize that

\section{H.6. Entrepreneurial motivation influences entrepreneurial intention.}

We represents in figure 3 the model of entrepreneurial culture proposed by Stephan [21] and adopted by Barbosa and al. [1]. Stephan [21] note that these five dimensions; looking for opportunities; Entrepreneurial traits; taking responsibility; Managerial skills and the entrepreneurial motivation are the different facets of the model represents the facets of entrepreneurial culture. While the fear of managing business is negatively related to entrepreneurial culture and entrepreneurial intention [1].

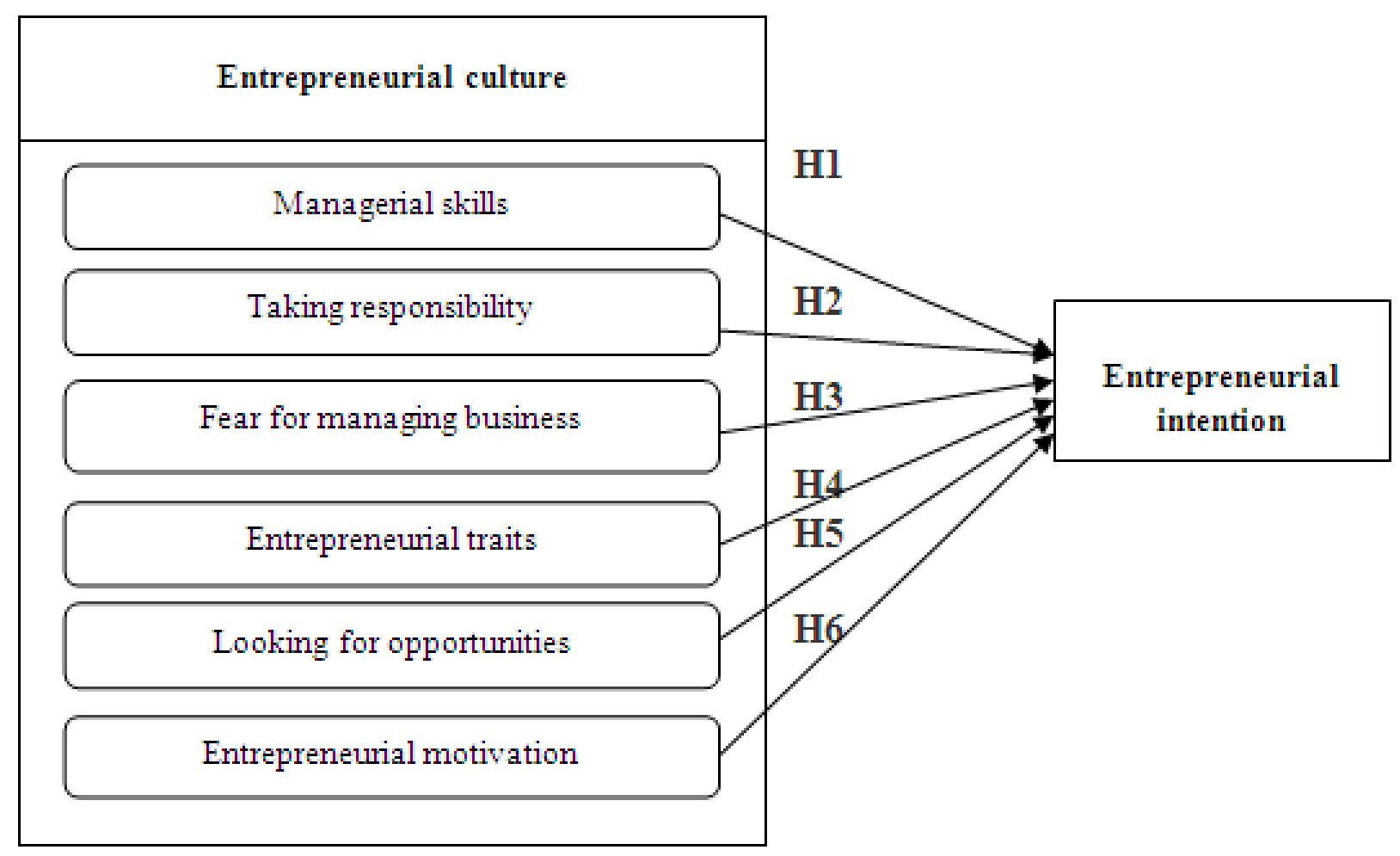

Figure 3. Research model 


\section{Methodology}

In our research, we are interested in engineering schools' students because of their relationships with enterprises. We carry out a cross cultural study in Morocco and Canada. We opted for a convenience sample. We addressed our questionnaire to 140 students of engineering school of Tetouan in Morocco and engineering school of university of Ottawa in Canada; 70 questionnaires for each sample. We received 53 valid responses from Moroccan students and 59 valid responses from Canadian students. We present the descriptive statistics of our samples and the response rates in table 1 (see appendix).

We opt for the survey as the data collect method since we aim to collect quantitative data. We refer to Barbosa and al. [1] and we adopt their questionnaire because we believe that it discerns the different facets of entrepreneurial culture.

In this research, we are interested in personal entrepreneurial culture of engineering students and not their perception of their national entrepreneurial culture. Therefore, we adapted the items of the original questionnaire. We replaced the terms of "in my country the majority of people are" by "I am". Hence, we collected more personal and specific answers. Responses will be measured using a 10-point Likert scale where 1 means you totally disagree and 10 means you totally agree. The questionnaire is composed of 7 sections dealing with the 7 variables and 26 items (we measure the dependent variable with a single item and independent ones with 25 items).

In this research, we opt for face-to-face interviews and we have reasonable response rates ( $84 \%$ of Canadian sample and $76 \%$ of Moroccan one).

\section{Results}

We present the coefficients of Chronobach alpha for each group of items in table 2 . The results indicate a reasonable reliability of our variables (see appendix). Then, we analyzed our research variables and we assessed the validity and the reliability of our research variables using 20.00 version of SPSS. We present our descriptive analyze in tables $3,4,5$ and 6 (see appendix)

As shown in table 4 and table 6 , our results indicate that Canadian engineering students are more attracted to entrepreneurship than the Moroccan ones. The percentage of willingness to entrepreneurship is 24.5 percent for Moroccan respondents and 35 percent for Canadian ones. This finding may be explained by the encouragement of Canadian federal government to technology transfer and academic entrepreneurship. On the other hand, Moroccan academic entrepreneur face different barriers related to entrepreneurship such as the universities' bureaucracy, the lack of exclusive rights protection, the lack of a common organizational culture and the lack of intellectual property protection. These barriers discourage students to consider self-employment.

Concerning the dimensions of entrepreneurial culture, the results as presented in tables 2 and 4 indicate some differences between our two samples. Entrepreneurial culture of our Canadian respondents seems to be more developed. In comparison with Moroccan sample, Canadian respondents show higher level of managerial skills and entrepreneurial traits, greater tendency to take responsibility and less fear of managing business. However, the Moroccan sample indicates a higher level of entrepreneurial motivation and almost the same level of predisposition to look for opportunities.

In fact, our research is based on a previous literature indicating that there is no significant impact of entrepreneurial culture on entrepreneurial intention [1]. Similarly, as shown in tables 7 and 8 , our findings reveal some insignificant variables using 0.05 as the critical significance level.

Indeed, for the Moroccan sample, our results indicate that there is no significant impact of these four variables; taking responsibility, fear of managing business, entrepreneurial traits and entrepreneurial motivation on entrepreneurial intention of Moroccan engineering students. Hence, we reject hypothesizes 2, 3, 4 and $6(\mathrm{P}>0.05)$. However, we approve that "managerial skills" and "looking for opportunities" influence the entrepreneurial intention of Moroccan engineering students $(P<0.05)$. Moreover, we confirm the positive correlation between these two independent variables; "managerial skills" and "looking for opportunities" with the entrepreneurial intention (1> Pearson correlation $>0.5$ ). Hence, we confirm hypothesizes 1 and 5 .

For the Canadian sample, our results indicate that there is no significant impact of these three variables; fear of managing business, entrepreneurial traits and taking responsibility on entrepreneurial intention of Moroccan engineering students. Hence, we reject hypothesizes 2, 3 and $4(\mathrm{P}>0.05)$. However, we approve that these independent variables; managerial skills, looking for opportunities and entrepreneurial motivation influence the entrepreneurial intention of Canadian engineering students $(\mathrm{P}<0.05)$. Moreover, we confirm the positive correlation of these three variables $(1>$ Pearson correlation $>0.5)$. Hence, we confirm hypotheses 1,5 and 6 .

It would appear that "managerial skills" and "looking for opportunities" are critical determining factors of entrepreneurial intention of both Moroccan and Canadian engineering students. While, entrepreneurial motivation influences only the entrepreneurial intention of our Canadian respondents.

In accordance with previous studies, the majority of entrepreneurial culture dimensions do not have a significant impact on entrepreneurial intention. For instance, Barbosa and al. [1] carry out a cross cultural study to assess the impact of entrepreneurial culture on entrepreneurial intention of French and Brazilian students. They emphasize that there is no direct impact of entrepreneurial intention on entrepreneurial culture. They explain that this relationship may be moderated or mediated by the direct antecedents of intention proposed in the theory of planned behavior, namely, 
attitudes and social norms [21].

\section{Conclusions}

In this research, we follow Barbosa and al. [1] and we assessed the impact of entrepreneurial culture on entrepreneurial intention. We addressed our questionnaire to students of engineering schools from Morocco and Canada. We chose two countries with different economic conditions and we found similar results; For both samples, "managerial skills" and "looking for opportunities" are two facets of entrepreneurial culture that determine the entrepreneurial intention of engineering school students. For Canadian respondents entrepreneurial intention is also determined by entrepreneurial motivation.

Finally, it must be noted that our research has some limits such as the limited number of cultural contexts (only two countries; Canada and Morocco). Moreover, the rejection of 4 hypotheses in the Moroccan case and 3 hypotheses in the Canadian case may be explained by the reduced number of respondents which may be one of our research limits. The hypotheses' rejection may also be explained by the mediating and the moderating factors of the relationship between entrepreneurial culture and entrepreneurial intention which may be a path for future research.

\section{Appendix}

Table 1. Descriptive statistics of the samples

\begin{tabular}{|c|c|c|c|c|}
\hline & \multicolumn{2}{|c|}{ Canadian sample } & \multicolumn{2}{|c|}{ Moroccan sample } \\
\hline Size sample & \multicolumn{2}{|c|}{70} & \multicolumn{2}{|c|}{70} \\
\hline $\begin{array}{l}\text { Students' average } \\
\text { age }\end{array}$ & \multicolumn{2}{|c|}{20} & \multicolumn{2}{|c|}{21} \\
\hline \multirow{2}{*}{ Gender } & Male & Female & Male & Female \\
\hline & 35 & 35 & 35 & 35 \\
\hline $\begin{array}{c}\text { Socio-economic } \\
\text { status }\end{array}$ & \multicolumn{2}{|c|}{ Students } & \multicolumn{2}{|c|}{ Students } \\
\hline & \multicolumn{2}{|c|}{$\begin{array}{c}\text { Canadian } \\
\text { respondents }\end{array}$} & \multicolumn{2}{|c|}{$\begin{array}{l}\text { Moroccan } \\
\text { respondents }\end{array}$} \\
\hline $\mathrm{N}$ & \multicolumn{2}{|c|}{59} & \multicolumn{2}{|c|}{53} \\
\hline Response rates & \multicolumn{2}{|c|}{$84 \%$} & \multicolumn{2}{|c|}{$76 \%$} \\
\hline $\begin{array}{c}\text { Students' average } \\
\text { age }\end{array}$ & \multicolumn{2}{|c|}{20} & \multicolumn{2}{|c|}{21} \\
\hline \multirow{2}{*}{ Gender } & Male & Female & Male & Female \\
\hline & 30 & 29 & 25 & 28 \\
\hline $\begin{array}{c}\text { Students' average } \\
\text { age } \\
\end{array}$ & \multicolumn{2}{|c|}{20} & \multicolumn{2}{|c|}{21} \\
\hline $\begin{array}{c}\text { Socio-economic } \\
\text { status }\end{array}$ & \multicolumn{2}{|c|}{ Students } & \multicolumn{2}{|c|}{ Students } \\
\hline
\end{tabular}

Table 2. The coefficients of Chronobach alpha for each group of items

\begin{tabular}{|c|c|c|c|}
\hline \multirow{2}{*}{ Variables } & \multirow{2}{*}{ Items } & \multicolumn{2}{|c|}{ Cronobach alpha } \\
\hline & & Canadian sample & Moroccan sample \\
\hline Managerial skills & $\begin{array}{c}\text { You are able to solve difficult and complex problems } \\
\text { You are able to actively manage unexpected situations } \\
\text { You believe in your own abilities } \\
\text { You maintain serenity when you are facing difficulties at work, since you } \\
\text { can rely on your own abilities } \\
\text { You improvise easily when unexpected changes occur }\end{array}$ & 0.831 & 0.813 \\
\hline Taking responsibility & $\begin{array}{c}\text { You think making quality work is your responsibility } \\
\text { You are accustomed to take responsibility for the things you do } \\
\text { You like to perform tasks of great responsibility, even if they require extra } \\
\text { work }\end{array}$ & 0.75 & 0.573 \\
\hline $\begin{array}{c}\text { Fear of managing a } \\
\text { business }\end{array}$ & $\begin{array}{c}\text { You don't try to start a new business, because you're afraid of change } \\
\text { You have a tendency to avoid uncertain situations } \\
\text { You don't start a new business because you hesitate to take risks } \\
\text { You don't start a new business because you doubt your abilities } \\
\text { You don't start a new business because you are afraid of taking } \\
\text { responsibility }\end{array}$ & 0.875 & 0.833 \\
\hline Entrepreneurial traits & $\begin{array}{c}\text { You value independence and autonomy } \\
\text { You value personal initiative } \\
\text { You value willingness to take risks }\end{array}$ & 0.697 & 0.539 \\
\hline $\begin{array}{l}\text { Looking for } \\
\text { opportunities }\end{array}$ & $\begin{array}{c}\text { You like to find several solutions to a problem } \\
\text { You try to exploit ambiguous situations, perceive them as opportunities } \\
\text { and act accordingly } \\
\text { You think about how you can exploit small markets } \\
\text { You look for new challenges }\end{array}$ & 0.687 & 0.707 \\
\hline $\begin{array}{l}\text { Entrepreneurial } \\
\text { motivation }\end{array}$ & $\begin{array}{l}\begin{array}{l}\text { You consider that investing in your own start-up and managing it is a } \\
\text { desirable career choice }\end{array} \\
\text { You consider that investing in your own start-up allows you to be free and } \\
\text { independent }\end{array}$ & 0.912 & 0.803 \\
\hline
\end{tabular}


Table 3. Descriptive analyze of the Moroccan sample

\begin{tabular}{|l|r|r|r|r|r|}
\hline & $N$ & Min & Max & Mean & $\begin{array}{c}\text { standard } \\
\text { deviation }\end{array}$ \\
\hline managerial.skills & 53 & 19,00 & 44,00 & 33,1887 & 6,70550 \\
taking.responsibility & 53 & 14,00 & 30,00 & 23,4151 & 3,72328 \\
fear.of.managing. & 53 & 6,00 & 44,00 & 24,1698 & 9,77386 \\
business & 53 & 13,00 & 30,00 & 21,6226 & 3,84421 \\
entrepreneurial.traits & 53 & 15,00 & 37,00 & 28,2264 & 4,75007 \\
looking.for.opportunities & 53 & 23,00 & 49,00 & 38,4717 & 6,21909 \\
entrepreneurial. & 53 & & & & \\
motivation & & & & \\
N valide (listwise) & 5 & & & & \\
\hline
\end{tabular}

Table 4. Descriptive statistics of the dependent variable of the Moroccan sample

\begin{tabular}{|rr|r|r|r|r|}
\hline & frequency & percent & valid percent & $\begin{array}{c}\text { cumulative } \\
\text { percent }\end{array}$ \\
\hline Valid & Yes & 13 & 24,5 & 24,5 & 24,5 \\
& No & 40 & 75,5 & 75,5 & 100,0 \\
& Total & 53 & 100,0 & 100,0 & \\
\hline
\end{tabular}

Table 5. Descriptive analyze of the Canadian sample

\begin{tabular}{|l|r|r|r|r|r|}
\hline & \multicolumn{1}{|c|}{$N$} & \multicolumn{1}{l|}{ Min } & \multicolumn{1}{l|}{ Max } & Mean & S.deviation \\
\hline managerial.skills & 59 & 28,00 & 48,00 & 39,1525 & 4,90184 \\
taking.responsibility & 59 & 17,00 & 30,00 & 25,2542 & 3,51152 \\
fear.of.managing. & 59 & 5,00 & 48,00 & 23,7458 & 10,08514 \\
business & & & & & \\
entrepreneurial.traits & 59 & 18,00 & 30,00 & 24,5593 & 3,67316 \\
looking.for.opportunities & 59 & 13,00 & 40,00 & 28,3051 & 6,00934 \\
entrepreneurial. & 59 & 5,00 & 50,00 & 34,2881 & 10,97183 \\
motivation & & & & & \\
N valide (listwise) & 59 & & & & \\
\hline
\end{tabular}

Table 6. Descriptive statistics of the dependent variable of the Canadian sample

\begin{tabular}{|rr|r|r|r|r|}
\hline & frequency & percent & valid percent & $\begin{array}{c}\text { cumulative } \\
\text { percent }\end{array}$ \\
\hline Valid & Yes & 21 & 35.6 & 35.6 & 35.6 \\
& No & 38 & 64.4 & 64.4 & 100.0 \\
& 59 & 100.0 & 100.0 & \\
\hline
\end{tabular}


Table 7. Results of bivariate correlation of the first sample (Moroccan students) $(\mathrm{N}=53)$

\begin{tabular}{|c|c|c|c|c|c|c|c|c|}
\hline & & $\begin{array}{l}\text { Managerial } \\
\text { skills }\end{array}$ & $\begin{array}{c}\text { Taking } \\
\text { responsibility }\end{array}$ & $\begin{array}{c}\text { Fear of } \\
\text { managing } \\
\text { business }\end{array}$ & $\begin{array}{l}\text { Entrep. } \\
\text { traits }\end{array}$ & $\begin{array}{l}\text { Looking for } \\
\text { opportunities }\end{array}$ & $\begin{array}{l}\text { Entrep. } \\
\text { motivation }\end{array}$ & $\begin{array}{l}\text { Entrep. } \\
\text { intention }\end{array}$ \\
\hline Managerial skills & $\begin{array}{l}\text { pearson correlation } \\
\text { Sig. (2-tailed) }\end{array}$ & 1 & $\begin{array}{l}.659 \\
.000\end{array}$ & $\begin{array}{r}-.451 \\
.001\end{array}$ & $\begin{array}{l}.577 \\
.000\end{array}$ & $\begin{array}{l}.647 \\
.000\end{array}$ & $\begin{array}{l}.505 \\
.000\end{array}$ & $\begin{array}{l}.283 \\
.040\end{array}$ \\
\hline $\begin{array}{c}\text { Taking } \\
\text { responsibility }\end{array}$ & $\begin{array}{l}\text { pearson correlation } \\
\text { Sig. (2-tailed) }\end{array}$ & $\begin{array}{l}.659 \\
.000 \\
\end{array}$ & 1 & $\begin{array}{l}.530 \\
.000\end{array}$ & $\begin{array}{l}.515 \\
.000 \\
\end{array}$ & $\begin{array}{l}.613 \\
.000\end{array}$ & $\begin{array}{l}.602 \\
.000\end{array}$ & $\begin{array}{l}.135 \\
.336 \\
\end{array}$ \\
\hline $\begin{array}{c}\text { Fear of managing } \\
\text { business }\end{array}$ & $\begin{array}{l}\text { pearson correlation } \\
\text { Sig. (2-tailed) }\end{array}$ & $\begin{array}{l}-.451 \\
.001 \\
\end{array}$ & $\begin{array}{l}-.530 \\
.000 \\
\end{array}$ & 1 & $\begin{array}{ll}-.446 \\
.001\end{array}$ & $\begin{array}{l}.227 \\
.103 \\
\end{array}$ & $\begin{array}{l}.261 \\
.059 \\
\end{array}$ & $\begin{array}{l}-.131 \\
.351 \\
\end{array}$ \\
\hline Entrep. traits & $\begin{array}{l}\text { pearson correlation } \\
\text { Sig. (2-tailed) }\end{array}$ & $\begin{array}{l}.577 \\
.000\end{array}$ & $\begin{array}{l}.515 \\
.000\end{array}$ & $\begin{array}{l}-.227 \\
.103 \\
\end{array}$ & 1 & $\begin{array}{l}.598 \\
.000\end{array}$ & $\begin{array}{l}.466 \\
.000\end{array}$ & $\begin{array}{l}.208 \\
.136\end{array}$ \\
\hline $\begin{array}{l}\text { Looking for } \\
\text { opportunities }\end{array}$ & $\begin{array}{l}\text { pearson correlation } \\
\text { Sig. (2-tailed) }\end{array}$ & $\begin{array}{l}.647 \\
.000\end{array}$ & $\begin{array}{l}.613 \\
.000\end{array}$ & $\begin{array}{l}-.227 \\
.103\end{array}$ & $\begin{array}{l}.598 \\
.000\end{array}$ & 1 & $\begin{array}{l}.700 \\
.000\end{array}$ & $\begin{array}{l}.281 \\
.042\end{array}$ \\
\hline Entrep. motivation & $\begin{array}{l}\text { pearson correlation } \\
\text { Sig. (2-tailed) }\end{array}$ & $\begin{array}{l}.505 \\
.000\end{array}$ & $\begin{array}{l}.602 \\
.000\end{array}$ & $\begin{array}{l}-.261 \\
.059\end{array}$ & $\begin{array}{l}.466 \\
.000\end{array}$ & $\begin{array}{l}.700 \\
.000\end{array}$ & 1 & $\begin{array}{l}.200 \\
.151\end{array}$ \\
\hline Entrep. Intention & $\begin{array}{l}\text { pearson correlation } \\
\text { Sig. (2-tailed) }\end{array}$ & $\begin{array}{l}.283 \\
.040\end{array}$ & $\begin{array}{l}.135 \\
.336\end{array}$ & $\begin{array}{l}.131 \\
.351\end{array}$ & $\begin{array}{l}.208 \\
.136\end{array}$ & $\begin{array}{l}.281 \\
.042\end{array}$ & $\begin{array}{l}.200 \\
.151\end{array}$ & 1 \\
\hline
\end{tabular}

Table 8. Results of bivariate correlation of the second sample (Canadian students) $(\mathrm{N}=59)$

\begin{tabular}{|c|c|c|c|c|c|c|c|c|}
\hline & & $\begin{array}{l}\text { Managerial } \\
\text { skills }\end{array}$ & $\begin{array}{c}\text { Taking } \\
\text { responsibility }\end{array}$ & $\begin{array}{c}\text { Fear of } \\
\text { managing } \\
\text { business }\end{array}$ & $\begin{array}{l}\text { Entrep. } \\
\text { traits }\end{array}$ & $\begin{array}{l}\text { Looking for } \\
\text { opportunities }\end{array}$ & $\begin{array}{c}\text { Entrep. } \\
\text { motivation }\end{array}$ & $\begin{array}{l}\text { Entrep. } \\
\text { intention }\end{array}$ \\
\hline Managerial skills & $\begin{array}{c}\text { pearson correlation } \\
\text { Sig. (2-tailed) }\end{array}$ & 1 & $\begin{array}{l}.546 \\
.000\end{array}$ & $\begin{array}{c}-.270 \\
.038 \\
\end{array}$ & $\begin{array}{l}.544 \\
.000\end{array}$ & $\begin{array}{l}.513 \\
.000\end{array}$ & $\begin{array}{l}.439 \\
.001\end{array}$ & $\begin{array}{l}.368 \\
.004\end{array}$ \\
\hline $\begin{array}{c}\text { Taking } \\
\text { responsibility }\end{array}$ & $\begin{array}{c}\text { pearson correlation } \\
\text { Sig. (2-tailed) }\end{array}$ & $\begin{array}{l}.546 \\
.000\end{array}$ & 1 & $\begin{array}{c}-.087 \\
.511 \\
\end{array}$ & $\begin{array}{l}.386 \\
.003\end{array}$ & $\begin{array}{l}.433 \\
.001\end{array}$ & $\begin{array}{l}.186 \\
.157\end{array}$ & $\begin{array}{l}.215 \\
.102\end{array}$ \\
\hline $\begin{array}{c}\text { Fear of managing } \\
\text { business }\end{array}$ & $\begin{array}{c}\text { pearson correlation } \\
\text { Sig. (2-tailed) }\end{array}$ & $\begin{array}{c}-.270 \\
.038 \\
\end{array}$ & $\begin{array}{c}-.087 \\
.511 \\
\end{array}$ & 1 & $\begin{array}{c}-.184 \\
.164 \\
\end{array}$ & $\begin{array}{c}-.320 \\
.013 \\
\end{array}$ & $\begin{array}{l}-.347 \\
.007 \\
\end{array}$ & $\begin{array}{l}-.168 \\
.203 \\
\end{array}$ \\
\hline Entrep. traits & $\begin{array}{l}\text { pearson correlation } \\
\text { Sig. (2-tailed) }\end{array}$ & $\begin{array}{l}.544 \\
.000\end{array}$ & $\begin{array}{l}.386 \\
.003\end{array}$ & $\begin{array}{l}-.184 \\
.164\end{array}$ & 1 & $\begin{array}{l}.497 \\
.000\end{array}$ & $\begin{array}{l}.492 \\
.000\end{array}$ & $\begin{array}{l}.224 \\
.088\end{array}$ \\
\hline $\begin{array}{l}\text { Looking for } \\
\text { opportunities }\end{array}$ & $\begin{array}{c}\text { pearson correlation } \\
\text { Sig. (2-tailed) }\end{array}$ & $\begin{array}{l}.513 \\
.000 \\
\end{array}$ & $\begin{array}{l}.433 \\
.001 \\
\end{array}$ & $\begin{array}{l}-.320 \\
.013 \\
\end{array}$ & $\begin{array}{l}.497 \\
.000\end{array}$ & 1 & $\begin{array}{l}.601 \\
.000\end{array}$ & $\begin{array}{l}.420 \\
.001 \\
\end{array}$ \\
\hline Entrep. motivation & $\begin{array}{l}\text { pearson correlation } \\
\text { Sig. (2-tailed) }\end{array}$ & $\begin{array}{l}.439 \\
.001 \\
\end{array}$ & $\begin{array}{l}.186 \\
.157 \\
\end{array}$ & $\begin{array}{l}-.347 \\
.007 \\
\end{array}$ & $\begin{array}{l}.492 \\
.000 \\
\end{array}$ & $\begin{array}{l}.601 \\
.000 \\
\end{array}$ & 1 & $\begin{array}{l}.465 \\
.000 \\
\end{array}$ \\
\hline Entrep. Intention & $\begin{array}{c}\text { pearson correlation } \\
\text { Sig. (2-tailed) }\end{array}$ & $\begin{array}{l}.368 \\
.004\end{array}$ & $\begin{array}{l}.215 \\
.102 \\
\end{array}$ & $\begin{array}{l}-.168 \\
.203\end{array}$ & $\begin{array}{l}.224 \\
.088\end{array}$ & $\begin{array}{l}.420 \\
.001\end{array}$ & $\begin{array}{l}.465 \\
.000\end{array}$ & 1 \\
\hline
\end{tabular}

**. correlation is significant at the 0.01 level (2-tailed).

*. correlation is significant at the 0.05 level (2-tailed)

\section{REFERENCES}

[1] S. D Barbosa, W. Marinho De Oliveira, A. Fayolle, F. Vidal Barbosa. Perceptions culturelles et intention d'entreprendre: Une comparaison entre des étudiants brésiliens et français, Revue internationale PME: Économie et gestion de la petite et moyenne entreprise, Vol. 23, N. 2, 9-41, 2010.

[2] R. Remeikiene, G. Startiene. Does the interaction between entrepreneurship and unemployment exist? Economics and management, N. 14, 903-911, 2015

[3] M. B. Low, E. Abrahamson. Movements, bandwagons, and clones: Industry evolution and the entrepreneurial process, Journal of Business Venturing, Vol. 12, N. 6, 435-457, 1997

[4] R. D. Ireland, M. A. Hitt, S. M. Camp, D. L. Sexton. Integrating entrepreneurship and strategic management actions to create firm wealth, The Academy of Management Executive, Vol. 15, N. 1, 49-63, 2001

[5] G. E. Hills. Variations in university entrepreneurship education: An empirical study of an evolving field, Journal of business venturing, Vol. 3, N. 2, 109-122, 1988
[6] A. Fayolle, B. Gailly, N. Lassas-Clerc. Assessing the impact of entrepreneurship education programmes: a new methodology, Journal of European industrial training, Vol. 30, N. 9, 701-720, 2006

[7] V. Souitaris, S. Zerbinati, A. Al-Laham. Do entrepreneurship programmes raise entrepreneurial intention of science and engineering students? The effect of learning, inspiration and resources, Journal of Business venturing, Vol. 22. N. 4, 566-591, 2007

[8] A. Do Paco, J. Ferreira, M. Raposo, R. G. Rodrigues, A. Dinis. Entrepreneurial intention among secondary students: findings from Portugal, International Journal of Entrepreneurship and Small Business, Vol.13, N.1, 92-106, 2011

[9] C. S. Choy, J. Kuppusamy, M. Jusoh. Entrepreneurial careers among business graduates: match-making using theory of planned behavior, International Journal of Entrepreneurship, Vol. 9, N. 67, 2005

[10] M. Guerrero, J. Rialp, D. Urbano. The impact of desirability and feasibility on entrepreneurial intentions: a structural equation model, Int Entrep Manage J, Vol. 4, N.1, 35-50, 2008 
[11] H. Zhao, S. E. Seibert, G. T. Lumpkin. The relationship of personality to entrepreneurial intentions and performance: A meta-analytic review, Journal of management, Vol.36, N.2, 381-404, 2010

[12] S. Zamberi Ahmad, S. Roland Xavier, A. Rahim Abu Bakar. Examining entrepreneurial intention through cognitive approach using Malaysia GEM data, Journal of Organizational Change Management, Vol.27, N.3, 449-464, 2014

[13] J. M. Crant. The proactive personality scale as a predictor of entrepreneurial intentions, Journal of small business management, Vol.34, N.3, 42, 1996

[14] A. Maâlaoui, S. Castellano, I. Safraou, M. Bourguiba. An exploratory study of seniorpreneurs: a new model of entrepreneurial intentions in the French context, International Journal of Entrepreneurship and Small Business, Vol.20, N.2, 148-164, 2013

[15] A. Shapero. Social dimensions of entrepreneurship, In C. A. Kent et al. (Eds.), The encyclopedia of entrepreneurship (pp. 72-89). Englewood Cliffs, NJ: Prentice-Hall, 1982

[16] I. Ajzen. The theory of planned behavior, Organizational Behavior and Human Decision Processes, Vol.50, 179-211, 1991

[17] P. B. Robinson, D. Stimpson, J. C. Huefner, H. K. Hunt. An attitude approach to the prediction of entrepreneurship, Entrepreneurship Theory and Practice, Vol.15, N.4, 13-31, 1991

[18] N. Krueger. The impact of prior entrepreneurial exposure on perceptions of new venture feasibility and desirability, Entrepreneurship: Theory and practice, Vol.18, N.1, 5-22, 1993

[19] N. F. Krueger, D. Brazeal. Entrepreneurial potential and potential entrepreneurs, Entrepreneurship Theory and Practice, Vol.18, N.3, 91-104, 1994

[20] P. Davidsson. Culture, structure and regional levels of entrepreneurship, Entrepreneurship \& Regional Development, Vol.7, N.1, 41-62, 1995

[21] U. Stephan. Culture of Entrepreneurship (C-Ent), Dresden University of Technology, 2007

[22] I. Marti, D. Courpasson, S. D. Barbosa. Living in the fishbowl, generating an entrepreneurial culture in a local community in Argentina. Journal of Business Venturing, Vol.28, N.1, 10-29, 2013
[23] C. Kolb, M. Wagner. Crowding in or crowding out: the link between academic entrepreneurship and entrepreneurial traits, The Journal of Technology Transfer, Vol.40, N.3, 387-408, 2015

[24] R. Espíritu-Olmos, M. A. Sastre-Castillo. Personality traits versus work values: Comparing psychological theories on entrepreneurial intention, Journal of Business Research, Vol.68, N, 7, 1595-1598, 2015

[25] A. K. Gupta, V. Govindarajan. Business unit strategy, managerial characteristics, and business unit effectiveness at strategy implementation, Academy of Management Journal, Vol.27, N.1, 25-41, 1984

[26] J. O. Ekore, O. C. Okekeocha. Fear of entrepreneurship among university graduates: a psychological analysis, International Journal of Management, Vol.29, N.2, 515, 2012

[27] E. J. Douglas. Reconstructing entrepreneurial intentions to identify predisposition for growth, Journal of Business Venturing, Vol.28, N.5, 633-651, 2013

[28] D. Miller. A downside to the entrepreneurial personality?, Entrepreneurship Theory and Practice, Vol.39, N.1, 1-8, 2015

[29] V. C. Hahn, M. Frese, C. Binnewies, A. Schmitt. Happy and Proactive? The Role of Hedonic and Eudaimonic Well Being in Business Owners' Personal Initiative, Entrepreneurship theory and practice, Vol.36,N.1, 97-114, 2012

[30] W. Bönte, V. D. Procher, D. Urbig. Biology and Selection Into Entrepreneurship-The Relevance of Prenatal Testosterone Exposure, Entrepreneurship Theory and Practice, 2015

[31] M. S. Cardon, D. A. Gregoire, C. E. Stevens, P. C. Patel. Measuring entrepreneurial passion: Conceptual foundations and scale validation, Journal of Business Venturing, Vol.28, N. 3, 373-396, 2013

[32] E. A. Locke, G. P. Latham. What should we do about motivation theory? Six recommendations for the twenty-first century, Academy of Management Review Vol.9, N.3, 388403, 2004

[33] E. L. Eijdenberg, E. Masurel. Entrepreneurial motivation in a least developed country: Push factors and pull factors among MSEs, Uganda. Journal of Enterprising Culture, Vol.21, N.1, $19-43,2013$

[34] S. Shane, E. Locke, C. J. Collins. Entrepreneurial motivation. Human Resource Management Review, Vol.13, N.2, 257280, 2003. 